\title{
A mortality study of coke oven workers in two South Wales integrated steelworks
}

\author{
G. M. DAVIES \\ From the British Steel Corporation, Welsh Laboratory and Strip Mill Products, Port Talbot, Glamorgan
}

ABSTRACT Six hundred and ten coke oven personnel were studied retrospectively over a period of 11 years (1954-65). During this time 82 died, 88 retired and 80 left, but all were traced. The Standardised Mortality Ratios (SMRs) have been calculated for four principal causes which have then been further analysed into 30 subgroups. The work was limited because the population was small and the records not detailed enough to analyse the mortality rates according to environmental exposures. Differences between SMRs obtained at the two works were quite marked (73 and 98) and the overall SMR of $85 \%$ was better than expected. The observed number of deaths from respiratory disease, malignant neoplasms and all other causes excluding cardiovascular, was very near that expected, but the numbers of deaths from cardiovascular disease and in particular arteriosclerotic disease, showed a significant deficit.

Studies of death rates according to occupation have indicated that mortality from cancer is higher than normal in the carbonising and associated industries. Kennaway and Kennaway (1947) studying the certified deaths during 1921-38 from cancer in gas workers found that the observed number was 29 more than that expected from a population of 16000 , an increase of $84 \%$. Doll (1952) studied 840 London gas companies' pensioners over 60 years of age who died in the period 1939-48, and estimated an expected 10.4 deaths from lung cancer, using the Registrar General's data for England and Wales, and an expected 13.8 from the data for London. The observed number of 25 was significantly different at the $\mathbf{0 . 0 0 1}$ and the 0.01 probability levels respectively. Reid and Buck (1956) found no excess mortality rates from 1949 to 1954 from either general or respiratory cancer in coking plant workers. Doll et al. (1965) compared the mortality rates between groups of gas workers selected according to occupation over a period of eight years. Their findings indicated that rates varied with occupation and the highest at risk were those in horizontal retort houses. Among all retort workers there was a $69 \%$ increase in lung cancer and a $126 \%$ increase in bronchitis. There were also indications of a slightly higher mortality from cancer of the bladder (observed $=5$ : expected $=$ 2.9) in those with heavy exposure in Occupational

Received for publication 5 July 1976

Accepted for publication 7 July 1977
Class $\mathrm{A}$, and it was deduced that this probably reflected an occupational hazard; in addition, cancer of the scrotum had not been eradicated entirely.

Kreyburg (1959) equated 3:4 benzpyrene pollution in one of the coke ovens he studied in Norway to 5000 cigarettes a day for workers on a 40-hour week. Referring to the high correlation between mortality from lung cancer and cigarettes smoked, he commented on the lack of evidence of high mortality rates from lung cancer in the works he investigated.

In a series of six papers, Lloyd and Ciocco (1969), Robinson (1969), Redmond et al. (1969), Lloyd et ai. (1970), Lloyd (1971) and Redmond et al. (1972), studied mortality among American steelworkers and in particular among coke oven workers. Rates were compared with those for other steelworkers, and the lung cancer risks for coke oven workers were related to work areas, duration of employment and race. It was shown that the lung cancer risk for working topside for a period of five or more years was increased by a factor of ten.

In a recently published paper Mazumdar et al. (1975) analysed mortality rates from a population of 4661 coke oven workers from 12 North American steel plants. They concluded from their findings that there was an excess of respiratory cancer and mortality among men employed in certain occupations and this could be related to concentrations of coal tar pitch volatiles in the air and periods of exposure. 


\section{Method}

The study described in this paper was undertaken as part of a much larger survey of chronic bronchitis and air pollution in the steel industry (Lowe et al., 1968; Warner et al., 1969; Lowe et al., 1970). There are two coke plants concerned; the total number of coke oven workers involved was 610, 233 of whom were employed at one plant (A) and 377 at the other (B).

The population employed in the two works during May 1954 was enumerated retrospectively in 1964 and 1965 and was followed until June 1965, a period of 11 years. During this time 82 died, 88 retired and 80 left for reasons other than retirement but all were traced. All those who did not die were included in the population at risk which, therefore, comprised those still in the works, those retired and those who had left and were alive.

It had been hoped to group the employees, as in studies by other workers, into three categories according to their exposure to the coke ovens' fumes: those constantly exposed, those occasionally exposed and those rarely exposed. However, examination of the records available indicated that, in many cases, the job descriptions were not specific enough and that movements within the departments had not been fully recorded. It was therefore impossible with many of the workers to evaluate exposure so the whole population was considered as one group with respect to coke oven exposure.

At the time of the follow-up, the population was divided into three categories: those who were still in the works or had died while still employed by the firm; those who had retired or had died during retirement; and those who had left for reasons other than retirement, some of whom had subsequently died.

The first two groups were fairly easy to trace except for those who had retired and were not eligible for company pensions. In these cases the company records had often lapsed and further investigations had to be undertaken, but the majority of the men in the first two groups were adequately covered by records available in the Personnel Employment Departments of the respective works. It was possible in many cases to cross-check information obtained from the pension records and the personnel employment records.

The third group, numbering 65 , was somewhat more difficult to trace. The first approach was to send out questionnaires with stamped and addressed envelopes in which the completed data could be returned. As a result of this initial contact, 24 useful complete replies were received, nine were returned as 'not known at this address' and 32 were not answered.

The second approach was made personally to the last-known addresses of those from whom completed questionnaires had not been received. Information was obtained about the reasons for not replying and in several cases new addresses were obtained to which further questionnaires were sent. In other cases, reliable information was received from relatives who had seen or communicated with the people concerned since the date of closure of the survey.

The National Insurance numbers of eight workers still untraced were supplied to the Ministry of Social Security, who informed us that all were alive. In this way, all the men in the original population were accounted for.

Tracing death records followed a similar pattern. In recent years the works Personnel Departments have kept copies of the death certificates. Where these were not available, the relatives were contacted with the object of finding out the date and place of death. If this proved unrewarding, the local registrars were approached and finally the dates and places of decease of many of those still unaccounted for were established at Somerset House. Finally the Registrar General was supplied with all the available information, which included the names and age of the deceased, the district in which the death was registered, and the appropriate reference to the data at Somerset House. The names and dates of birth of the small remaining group with no known date of death were also forwarded to the Registrar General. For all 82 cases, the causes and dates of death, as recorded on the death certificates, were obtained.

\section{Results}

Causes of death were divided into four main groups: malignant neoplasms, cardiovascular conditions, respiratory conditions, and other conditions. Each group was subdivided and the average mortality rates for each group and subgroup were calculated for the four middle years of the study, 1958-61 inclusive, from the Registrar General's Statistical Reviews, Part 1, Medical (1960-63). These data were used to compile Tables 2-5 of this paper, which were in turn used to produce Tables $1 \mathrm{a}, \mathrm{b}$ and $\mathrm{c}$. Tables 2-5 were compiled by multiplying the calculated mortality rates (averages for four years 1958-61) by the number of man-years at risk in each of the age ranges at works $A$ and $B$ thus producing the expected deaths. These are compared in the Tables with the observed deaths obtained from studying the death certificates. The number of man-years at risk was calculated by counting each man in every year of the survey for which he remained alive, and on each occasion he was allocated to the appropriate age group.

Hence the first column in each of Tables 1a, b and c, 2, 3, 4 and 5 describes the age group into which 
A mortality study of coke oven workers in two South Wales integrated steelworks

Table 1a Coke oven workers' observed and expected deaths at Works $A$ from four principal causes

\begin{tabular}{|c|c|c|c|c|c|c|c|c|c|c|c|}
\hline \multirow[t]{2}{*}{$\begin{array}{l}\text { Age range } \\
(y r)\end{array}$} & \multirow[t]{2}{*}{$\begin{array}{l}\text { Man-years } \\
1954-65\end{array}$} & \multicolumn{2}{|c|}{$\begin{array}{l}\text { Malignant neoplasms } \\
\text { ICD. Nos. } 140-205\end{array}$} & \multicolumn{2}{|c|}{$\begin{array}{l}\text { Cardiovascular } \\
\text { B. } 22,24-29,46(P t)\end{array}$} & \multicolumn{2}{|c|}{$\begin{array}{l}\text { Respiratory } \\
\text { B. } 30-32,46(P t)\end{array}$} & \multicolumn{2}{|c|}{ Others } & \multicolumn{2}{|c|}{ Total } \\
\hline & & Obs & $\operatorname{Exp}$ & Obs & $\operatorname{Exp}$ & Obs & $\operatorname{Exp}$ & Obs & $\operatorname{Exp}$ & Obs & $\operatorname{Exp}$ \\
\hline $\begin{array}{l}15-24 \\
25-44 \\
45-54 \\
55-64 \\
65-74 \\
75+\end{array}$ & $\begin{array}{r}56 \\
749 \\
494 \\
745 \\
431 \\
29\end{array}$ & $\begin{array}{l}5 \\
8 \\
1\end{array}$ & $\begin{array}{l}0.29 \\
1.00 \\
4.45 \\
5.01 \\
0.50\end{array}$ & $\begin{array}{r}1 \\
5 \\
10\end{array}$ & $\begin{array}{r}0.01 \\
0.39 \\
1.51 \\
7.30 \\
11.82 \\
2.36\end{array}$ & $\begin{array}{l}1 \\
5 \\
2\end{array}$ & $\begin{array}{l}\mathbf{0} \cdot 10 \\
0.37 \\
2 \cdot 37 \\
\mathbf{3} \cdot 69 \\
\mathbf{0 . 6 1}\end{array}$ & $\begin{array}{l}1 \\
4 \\
3 \\
1\end{array}$ & $\begin{array}{l}0.04 \\
0 \cdot 29 \\
0 \cdot 71 \\
2.08 \\
2.46 \\
0.48\end{array}$ & $\begin{array}{r}1 \\
2 \\
19 \\
23 \\
2\end{array}$ & $\begin{array}{r}0.05 \\
1.07 \\
3.59 \\
16.20 \\
22.98 \\
3.95\end{array}$ \\
\hline Totals & 2524 & 14 & $11 \cdot 25$ & 16 & $23 \cdot 39$ & 8 & $7 \cdot 14$ & 9 & 6.06 & 47 & 47.84 \\
\hline
\end{tabular}

Obs $=$ observed $; \exp =$ expected, in this and all subsequent tables.

Table 1b Coke oven workers' observed and expected deaths at Works B from four principal causes

\begin{tabular}{|c|c|c|c|c|c|c|c|c|c|c|c|}
\hline \multirow{2}{*}{$\begin{array}{l}\text { Age range } \\
\text { (yr) }\end{array}$} & \multirow{2}{*}{$\begin{array}{l}\text { Man-years } \\
1954-65\end{array}$} & \multicolumn{2}{|c|}{ Malignant neoplasms } & \multicolumn{2}{|c|}{ Cardiovascular } & \multicolumn{2}{|c|}{ Respiratory } & \multicolumn{2}{|c|}{ Others } & \multicolumn{2}{|l|}{ Total } \\
\hline & & Obs & $\operatorname{Exp}$ & Obs & $\operatorname{Exp}$ & Obs & $\operatorname{Exp}$ & Obs & $\operatorname{Exp}$ & Obs & $\operatorname{Exp}$ \\
\hline $\begin{array}{l}15-24 \\
25-44 \\
45-54 \\
55-64 \\
65-74 \\
75+\end{array}$ & $\begin{array}{r}106 \\
1819 \\
1093 \\
1015 \\
276 \\
4\end{array}$ & $\begin{array}{l}4 \\
3 \\
5\end{array}$ & $\begin{array}{l}0.01 \\
0.67 \\
2.20 \\
6.06 \\
3.21 \\
0.07\end{array}$ & $\begin{array}{l}6 \\
3 \\
2 \\
2\end{array}$ & $\begin{array}{l}0.01 \\
0.92 \\
3.35 \\
9.97 \\
7.57 \\
0.33\end{array}$ & $\begin{array}{l}2 \\
4\end{array}$ & $\begin{array}{l}0.22 \\
0.82 \\
3.22 \\
2.37 \\
0.08\end{array}$ & $\begin{array}{l}1 \\
2 \\
1\end{array}$ & $\begin{array}{l}0.07 \\
0.69 \\
1.56 \\
2.84 \\
1.57 \\
0.06\end{array}$ & $\begin{array}{r}1 \\
14 \\
7 \\
11 \\
2\end{array}$ & $\begin{array}{r}0.09 \\
2.50 \\
7.93 \\
22.09 \\
14.72 \\
0.54\end{array}$ \\
\hline
\end{tabular}

Table 1c Coke oven workers' observed and expected deaths at Works $A$ and $B$ from four principal causes

\begin{tabular}{|c|c|c|c|c|c|c|c|c|c|c|c|}
\hline \multirow{2}{*}{$\begin{array}{l}\text { Age range } \\
\text { (yr) }\end{array}$} & \multirow{2}{*}{$\begin{array}{l}\text { Man years } \\
1954-65\end{array}$} & \multicolumn{2}{|c|}{ Malignant neoplasms } & \multicolumn{2}{|c|}{ Cardiovascular } & \multicolumn{2}{|c|}{ Respiratory } & \multicolumn{2}{|c|}{ Others } & \multicolumn{2}{|l|}{ Total } \\
\hline & & Obs & Exp & Obs & $\operatorname{Exp}$ & Obs & $\operatorname{Exp}$ & Obs & $\operatorname{Exp}$ & Obs & $\operatorname{Exp}$ \\
\hline $\begin{array}{l}15-24 \\
25-44 \\
45-54 \\
55-64 \\
65-74 \\
75+\end{array}$ & $\begin{array}{r}162 \\
2568 \\
1587 \\
1760 \\
707 \\
33\end{array}$ & $\begin{array}{r}4 \\
8 \\
13 \\
1\end{array}$ & $\begin{array}{r}0.01 \\
0.96 \\
3.20 \\
10.51 \\
8.22 \\
0.57\end{array}$ & $\begin{array}{r}7 \\
8 \\
12 \\
2\end{array}$ & $\begin{array}{r}0.02 \\
1.31 \\
4.86 \\
17 \cdot 27 \\
19.39 \\
2.69\end{array}$ & $\begin{array}{l}3 \\
5 \\
6\end{array}$ & $\begin{array}{l}0.32 \\
1.19 \\
5.59 \\
6.06 \\
0.69\end{array}$ & $\begin{array}{l}2 \\
2 \\
5 \\
3 \\
1\end{array}$ & $\begin{array}{l}0.08 \\
0.98 \\
2.27 \\
4.92 \\
4.03 \\
0.54\end{array}$ & $\begin{array}{r}2 \\
16 \\
26 \\
34 \\
4\end{array}$ & $\begin{array}{r}0 \cdot 14 \\
3 \cdot 57 \\
11 \cdot 52 \\
38 \cdot 29 \\
37 \cdot 70 \\
4 \cdot 49\end{array}$ \\
\hline Totals & 6837 & 26 & 23.47 & 29 & $45 \cdot 54$ & 14 & 13.85 & 13 & $12 \cdot 85$ & 82 & $95 \cdot 71$ \\
\hline
\end{tabular}

Table 2 Observed and expected* deaths at Works $A$ and $B$ from malignant neoplasms

\begin{tabular}{|c|c|c|c|c|c|c|c|c|c|c|c|c|c|c|c|}
\hline \multirow{2}{*}{$\begin{array}{l}\text { Age } \\
\text { range } \\
(y r)\end{array}$} & \multirow{2}{*}{$\begin{array}{l}\text { Man- } \\
\text { years } \\
1954-65\end{array}$} & \multicolumn{2}{|c|}{$\begin{array}{l}\text { Stomach } \\
151\end{array}$} & \multicolumn{2}{|c|}{$\begin{array}{l}\text { Rectum \& colon } \\
152,154\end{array}$} & \multicolumn{2}{|c|}{$\begin{array}{l}\text { Lung } \\
161,163\end{array}$} & \multicolumn{2}{|c|}{$\begin{array}{l}\text { Bladder \& kidney } \\
180,181\end{array}$} & \multicolumn{2}{|c|}{$\begin{array}{l}\text { Leukaemia } \\
204\end{array}$} & \multicolumn{2}{|c|}{ Others } & \multicolumn{2}{|c|}{ Total } \\
\hline & & Obs & Exp & Obs & Exp & Obs & $\operatorname{Exp}$ & Obs & $\operatorname{Exp}$ & Obs & $\operatorname{Exp}$ & Obs & $\operatorname{Exp}$ & Obs & $\operatorname{Exp}$ \\
\hline $\begin{array}{l}15-24 \\
25-34 \\
35-44 \\
45-54 \\
55-64 \\
65-74 \\
75+\end{array}$ & $\begin{array}{r}162 \\
1138 \\
1450 \\
1587 \\
1760 \\
707 \\
33\end{array}$ & $\begin{array}{l}1 \\
2 \\
1\end{array}$ & $\begin{array}{l}0 \cdot 01 \\
0 \cdot 10 \\
0 \cdot 43 \\
1 \cdot 52 \\
1 \cdot 32 \\
0 \cdot 10\end{array}$ & $\begin{array}{l}1 \\
1 \\
3\end{array}$ & $\begin{array}{l}0.02 \\
0.08 \\
0.30 \\
1.02 \\
1.08 \\
0.10\end{array}$ & $\begin{array}{l}1 \\
5 \\
2\end{array}$ & $\begin{array}{l}0.03 \\
0 \cdot 24 \\
1.43 \\
4.97 \\
2.99 \\
0 \cdot 10\end{array}$ & $\begin{array}{l}2 \\
1\end{array}$ & $\begin{array}{l}0.03 \\
0.14 \\
0.51 \\
0.47 \\
0.04\end{array}$ & & $\begin{array}{l}0.05 \\
0.08 \\
0.19 \\
0.15 \\
0.01\end{array}$ & $\begin{array}{l}1 \\
5\end{array}$ & $\begin{array}{l}0 \cdot 01 \\
0 \cdot 13 \\
0 \cdot 27 \\
0 \cdot 82 \\
2 \cdot 30 \\
2 \cdot 21 \\
0 \cdot 22\end{array}$ & $\begin{array}{r}4 \\
8 \\
13 \\
1\end{array}$ & $\begin{array}{r}0.01 \\
0.19 \\
0.77 \\
3.20 \\
10.51 \\
8.22 \\
0.57\end{array}$ \\
\hline Totals & 6837 & 4 & 3.48 & 5 & $2 \cdot 60$ & 8 & $9 \cdot 76$ & 3 & $1 \cdot 19$ & 0 & 0.48 & 6 & 5.96 & 26 & 23.47 \\
\hline
\end{tabular}

* Compiled from Registrar General (1960-63) Tables 2-17. 
Table 3 Observed and expected ${ }^{*}$ deaths at Works $A$ and $B$ from cardiovascular diseases

\begin{tabular}{|c|c|c|c|c|c|c|c|c|c|c|c|c|c|c|c|c|c|c|c|c|c|}
\hline \multirow[t]{2}{*}{$\begin{array}{l}\text { Age } \\
\text { range } \\
(y r)\end{array}$} & \multirow[t]{2}{*}{$\begin{array}{l}\text { Man- } \\
\text { years } \\
1954-65\end{array}$} & \multicolumn{2}{|c|}{$\begin{array}{l}\text { Vascular } \\
\text { lesions } \\
\text { affecting } \\
\text { CNS }\end{array}$} & \multicolumn{2}{|c|}{$\begin{array}{l}\text { Rheumatic } \\
\text { fever }\end{array}$} & \multicolumn{2}{|c|}{$\begin{array}{l}\text { Chronic } \\
\text { rheumatoid } \\
\text { heart } \\
\text { disease }\end{array}$} & \multicolumn{2}{|c|}{$\begin{array}{l}\text { Arteriosclerotic } \\
\text { heart } \\
\text { disease } \\
\text { including } \\
\text { coronary } \\
\text { disease } \\
\text { B.26a }\end{array}$} & \multicolumn{2}{|c|}{$\begin{array}{l}\text { Degenerative } \\
\text { heart } \\
\text { disease } \\
\text { B.26b }\end{array}$} & \multicolumn{2}{|c|}{$\begin{array}{l}\text { Other } \\
\text { heart } \\
\text { disease }\end{array}$} & \multicolumn{2}{|c|}{$\begin{array}{l}\text { Hypertension } \\
\text { with heart } \\
\text { disease }\end{array}$} & \multicolumn{2}{|c|}{$\begin{array}{l}\text { Hypertension } \\
\text { without } \\
\text { mention of } \\
\text { heart }\end{array}$} & \multicolumn{2}{|c|}{$\begin{array}{l}\begin{array}{l}\text { Other } \\
\text { circulatory } \\
\text { disease }\end{array} \\
\text { B.46(Pt) }\end{array}$} & \multicolumn{2}{|c|}{ Totai } \\
\hline & & Obs & $\operatorname{Exp}$ & Obs & $\operatorname{Exp}$ & Obs & $\operatorname{Exp}$ & Obs & Exp & Obs & $\operatorname{Exp}$ & Obs & $\operatorname{Exp}$ & Obs & $\operatorname{Exp}$ & Obs & Exp & Obs & Exp & Obs & $s$ Exp \\
\hline $\begin{array}{l}15-24 \\
25-44 \\
45-54 \\
55-64 \\
65-74 \\
75+\end{array}$ & $\begin{array}{r}162 \\
2588 \\
1587 \\
1760 \\
707 \\
33\end{array}$ & $\begin{array}{l}1 \\
2 \\
2\end{array}$ & $\begin{array}{l}0.20 \\
0.74 \\
3.40 \\
4.76 \\
0.73\end{array}$ & & $\begin{array}{l}0.01 \\
0.01\end{array}$ & $\begin{array}{l}1 \\
1\end{array}$ & $\begin{array}{l}0.18 \\
0.27 \\
0.47 \\
0.27 \\
0.02\end{array}$ & $\begin{array}{l}4 \\
1 \\
4 \\
1\end{array}$ & $\begin{array}{r}0.01 \\
0.68 \\
3.09 \\
10.15 \\
9.01 \\
0.73\end{array}$ & $\begin{array}{l}1 \\
1 \\
2\end{array}$ & $\begin{array}{l}0.01 \\
0.05 \\
0.16 \\
0.90 \\
2.17 \\
0.71\end{array}$ & 1 & $\begin{array}{l}0.06 \\
0.14 \\
0.64 \\
0.89 \\
0.14\end{array}$ & & $\begin{array}{l}0.02 \\
0.11 \\
0.59 \\
0.82 \\
0.10\end{array}$ & $\begin{array}{l}1 \\
1\end{array}$ & $\begin{array}{l}0.07 \\
0.19 \\
0.48 \\
0.44 \\
0.05\end{array}$ & 2 & $\begin{array}{l}0.05 \\
0.16 \\
0.63 \\
1.02 \\
0.21\end{array}$ & $\begin{array}{r}7 \\
8 \\
12 \\
2\end{array}$ & $\begin{array}{r}0.02 \\
1.31 \\
4.86 \\
17 \cdot 27 \\
19 \cdot 39 \\
2.69\end{array}$ \\
\hline Totals & 6837 & 5 & $9 \cdot 83$ & 0 & 0.02 & 2 & $1 \cdot 21$ & 10 & 23.67 & 4 & 4.00 & 1 & 1.87 & 70 & 1.64 & 2 & $1 \cdot 23$ & 52 & 2.07 & 29 & $45 \cdot 54$ \\
\hline
\end{tabular}

*Compiled from Registrar General (1960-63) Table 19.

Table 4 Observed and expected* deaths at Works $A$ and $B$ from respiratory diseases

\begin{tabular}{|c|c|c|c|c|c|c|c|c|c|c|c|}
\hline \multirow[t]{2}{*}{$\begin{array}{l}\text { Age range } \\
\text { (yr) }\end{array}$} & \multirow[t]{2}{*}{$\begin{array}{l}\text { Man-years } \\
1954-65\end{array}$} & \multicolumn{2}{|c|}{$\begin{array}{l}\text { Influenza } \\
\text { B.30 }\end{array}$} & \multicolumn{2}{|c|}{$\begin{array}{l}\text { Pneumonia } \\
\text { B.31 }\end{array}$} & \multicolumn{2}{|c|}{$\begin{array}{l}\text { Bronchitis } \\
\text { B.32 }\end{array}$} & \multicolumn{2}{|c|}{$\begin{array}{l}\text { Other respiratory diseases } \\
B .46(P t)\end{array}$} & \multicolumn{2}{|c|}{ Total } \\
\hline & & Obs & Exp & $O b s$ & Exp & $O b s$ & Exp & Obs & Exp & Obs & Exp \\
\hline $\begin{array}{l}15-24 \\
25-44 \\
45-54 \\
55-64 \\
65-74 \\
75+\end{array}$ & $\begin{array}{r}162 \\
2588 \\
1587 \\
1760 \\
707 \\
33\end{array}$ & $\begin{array}{l}1 \\
1\end{array}$ & $\begin{array}{l}0.05 \\
0.09 \\
0.32 \\
0.34 \\
0.04\end{array}$ & $\begin{array}{l}3 \\
2\end{array}$ & $\begin{array}{l}0.12 \\
0.30 \\
1 \cdot 12 \\
1.53 \\
0.29\end{array}$ & $\begin{array}{l}1 \\
1 \\
4\end{array}$ & $\begin{array}{l}0.09 \\
0.62 \\
3.47 \\
3.63 \\
0.32\end{array}$ & 1 & $\begin{array}{l}0.06 \\
0.18 \\
0.68 \\
0.56 \\
0.04\end{array}$ & $\begin{array}{l}3 \\
5 \\
6\end{array}$ & $\begin{array}{l}0.32 \\
1 \cdot 19 \\
5 \cdot 59 \\
6.06 \\
0.69\end{array}$ \\
\hline Totals & 6837 & 2 & 0.84 & 5 & $3 \cdot 36$ & 6 & $8 \cdot 13$ & 1 & $1 \cdot 52$ & 14 & 13.85 \\
\hline
\end{tabular}

* Compiled from Registrar General (1960-63) Table 19.

Table 5 Observed and expected* deaths at Works $A$ and $B$ from various causes

\begin{tabular}{|c|c|c|c|c|c|c|c|c|c|c|c|c|c|c|c|c|c|c|c|c|c|c|c|}
\hline \multirow[t]{2}{*}{$\begin{array}{l}\text { Age } \\
\text { range } \\
(y r)\end{array}$} & \multirow[t]{2}{*}{$\begin{array}{l}\text { Man- } \\
\text { years } \\
1954-65\end{array}$} & \multicolumn{2}{|c|}{$\begin{array}{l}\text { Infections } \\
B 1-17\end{array}$} & \multicolumn{2}{|c|}{$\begin{array}{l}\text { Unspecified } \\
\text { neoplasms } \\
\text { B19 }\end{array}$} & \multicolumn{2}{|c|}{$\begin{array}{l}\text { Diabetes } \\
\text { B2O }\end{array}$} & \multicolumn{2}{|c|}{$\begin{array}{l}\text { Anaemias } \\
\text { B21 }\end{array}$} & \multicolumn{2}{|c|}{$\begin{array}{l}\text { Gastro- } \\
\text { intestinal } \\
\text { B33-37 }\end{array}$} & \multicolumn{2}{|c|}{$\begin{array}{l}\text { Renal } \\
\text { B38-39 }\end{array}$} & \multicolumn{2}{|c|}{$\begin{array}{l}\text { Congenital } \\
B 4 I\end{array}$} & \multicolumn{2}{|c|}{$\begin{array}{l}\text { Senility } \\
\text { etc. } \\
\text { B45 }\end{array}$} & \multicolumn{2}{|c|}{$\begin{array}{l}\text { Trauma } \\
B 47-50\end{array}$} & \multicolumn{2}{|c|}{$\begin{array}{l}\text { Others } \\
\text { B46 (Rem) }\end{array}$} & \multicolumn{2}{|c|}{ Total } \\
\hline & & Obs & Exp & Obs & Exp & Obs & $\operatorname{Exp}$ & Obs & $\operatorname{Exp}$ & Obs & $\operatorname{Exp}$ & Obs & Exp & Obs & $\operatorname{Exp}$ & Obs & $\operatorname{Exp}$ & Obs & $\operatorname{Exp}$ & Obs & $\operatorname{Exp}$ & Obs & Exp \\
\hline $\begin{array}{l}5-24 \\
25-44 \\
45-54 \\
55-64 \\
65-74 \\
75+\end{array}$ & $\begin{array}{r}162 \\
2588 \\
1587 \\
1760 \\
707 \\
33\end{array}$ & 1 & $\begin{array}{l}0.2 \\
0.3 \\
0.8 \\
0.5 \\
0.02\end{array}$ & & $\begin{array}{l}0.03 \\
0.05 \\
0.1 \\
0.06 \\
0.01\end{array}$ & 1 & $\begin{array}{l}0.03 \\
0.05 \\
0.1 \\
0.02\end{array}$ & & $\begin{array}{l}0.01 \\
0.06 \\
0.03\end{array}$ & 1 & $\begin{array}{l}0.1 \\
0.3 \\
1.0 \\
0.9 \\
0.1\end{array}$ & $\begin{array}{l}4 \\
1\end{array}$ & $\begin{array}{l}0.1 \\
0.2 \\
0.4 \\
0.6 \\
0.1\end{array}$ & 1 & $\begin{array}{l}0.06 \\
0.05 \\
0.06 \\
0.03\end{array}$ & & $\begin{array}{l}0.01 \\
0.01 \\
0.02 \\
0.07 \\
0.11\end{array}$ & $\begin{array}{l}1 \\
1\end{array}$ & $\begin{array}{l}0 \cdot 1 \\
0.15 \\
0.9 \\
1.4 \\
0.8 \\
0.1\end{array}$ & & $\begin{array}{l}0.01 \\
0.3 \\
0.4 \\
0.98 \\
0.97 \\
0.10\end{array}$ & $\begin{array}{l}2 \\
2 \\
5 \\
3 \\
1\end{array}$ & $\begin{array}{l}0.11 \\
0.98 \\
2.27 \\
4.92 \\
4.03 \\
0.54\end{array}$ \\
\hline Total & 6837 & 2 & 1.82 & 0 & 0.25 & 1 & 0.20 & & 0.15 & 1 & $2 \cdot 40$ & 6 & 1.40 & 1 & 0.20 & & 0.22 & 2 & 3.45 & & $2 \cdot 76$ & 13 & $12 \cdot 850$ \\
\hline
\end{tabular}

* Compiled from Registrar General (1960-63) Table 19.

each man was placed annually as he passed through the 11 years of the survey. The second column in each of these tables describes the total of years lived by all the individuals in each group after entering into the survey. It should be noted that this is not necessarily the same as the years exposed to the coke oven environment.

Table 1c shows the breakdown of observed and expected deaths at both works into the four main groups and indicates an SMR for the total coke oven population at risk of $100 \times 82 / 95 \cdot 71(=85)$. Thus the population may be seen to have suffered lower death rates than the male population in
England and Wales. The main contributor to this result from the four main causes is the cardiovascular group in which there were only 29 deaths instead of an expected $45 \cdot 54$. This is a rate of 64 which is significantly different from the normal rate at the $\mathbf{P}=0.02$ level with 1 degree of freedom. The other three rates are not significantly different from normal, in fact the expected and observed numbers of deaths are very similar.

By subdividing the population under investigation into two parts according to the works in which they were employed it is possible to investigate the manner in which the rate from each group of cause of 
death at each works contributes to the total. Thus in Works A (Table 1a) the SMR for the total number of deaths was 47/47.84 (=98) which compares with $35 / 47 \cdot 87(=73)$ at Works B. Analysis of these figures according to the four groups of diseases indicates that in Works A, three of the four groups gave slightly higher numbers of observed deaths than expected while the fourth, cardiovascular group, more than compensated with 16 deaths instead of an expected 23.39. In Works $B$ the numbers of observed deaths were smaller than the expected numbers in all four groups but once again the cardiovascular group showed the biggest difference, 13 deaths instead of the expected $22 \cdot 15$. The other groups did not show large differences between the expected and observed numbers of deaths. Looking at each group according to total numbers of deaths in each age range, Table 1c indicates that in five of the six ranges there were fewer observed than expected deaths. This was particularly noticeable in the age range 55-64 where 38.29 deaths were expected and 26 were observed, an SMR of 68 . This figure was due to seven deaths instead of an expected 22.09 at Works B which more than compensated for 19 instead of an expected $16 \cdot 20$ at Works A. All four causative groups contributed towards this figure in Works B with cardiovascular conditions providing the biggest differences. Although the observed number of deaths was lower than the expected number in the cardiovascular group in the Works A age range 55-64, each of the other three groups in this age range had a larger number of observed deaths than expected.

The only other age range to show a marked difference was the 45-54 range in which 16 deaths occurred instead of an expected 11.52 in the total population. Here Works A had 2 observed deaths instead of an expected 3.59 , while Works B had 14 deaths instead of 7.93 and all four causative groups contributed.

\section{MALIGNANT NEOPLASMS}

The observed figure for malignant neoplasms, 26, was not significantly different from the expected number of 23.47 (Table 1c). The figures from each works indicate that at Works $\mathbf{A}$ there was a slightly higher number of observed deaths than expected, 14 instead of 11.25 (Table 1a) while at Works B the observed and expected numbers were the same, 12 and $12 \cdot 22$ respectively (Table $1 \mathrm{~b}$ ). In both works the 65-74 age range showed a somewhat higher observed number than expected producing a total in that range of 13 instead of $8 \cdot 22$. Table 2 provides a breakdown of the deaths from malignant neoplasms into subgroups. Examination of the totals in both the age ranges and subgroups indicates no significant differences and the 13 observed compared with the 8.22 in the 65-74 age range has no single main contributing causative subgroup.

\section{CARDIOVASCULAR}

It has already been shown that this group provides the most noticeable differences between the observed and expected number of deaths. Examination of Table 3 indicates that the single largest contributor to these differences is arteriosclerotic heart disease including coronary thrombosis (B.26a in the International List). In this subgroup there were 10 observed deaths instead of an expected 23.67, a difference which is significant at the $P=0.01$ level with 1 degree of freedom. The two age ranges contributing to this result are 55-64 and 65-74 where 1 death was observed instead of $10 \cdot 15$ and 4 instead of 9.01 respectively. Vascular lesions affecting the central nervous system (B.22), also showed a difference, 5 observed instead of 9.83 expected. Apart from B.46 (Pt) where 5 deaths were observed, compared with 2.07 expected, the remaining subgroups showed very good agreement between the observed and expected deaths.

\section{RESPIRATORY}

The observed and expected total numbers of deaths for both the subgroups and age ranges in Table 4 were very similar with no single pair of numbers differing significantly.

\section{OTHERS}

Table 5 provides a breakdown of other diseases into ten subgroups numbered according to the Registrar General's Abbreviated list. The overall total of observed deaths, 13 , is almost identical to the calculated expected number, $12 \cdot 85$. The only subgroup to show a difference was B38-39 Renal, in which there were 6 observed compared with 1.40 expected deaths, with the main contribution coming from the age range 55-64 in which there were 4 observed deaths instead of the expected $0 \cdot 40$.

\section{Discussion}

Within the limitations of the survey, including the comparatively small population of 610 studied and the inability to classify the personnel according to exposure, the results do not indicate a higher mortality rate than that expected; in fact, the reverse was true, the overall SMR being 85 .

The original population in 1954 was a working industrial population and as such would probably have been healthier than 'normal'. Whether this healthy worker effect would have persisted over the ten years of the survey is arguable. The position on this effect is complex and differing methods for dealing 
with it have been suggested in Special Communications of the Journal of Occupational Medicine (1975) and by McMichael (1976). However, bearing the limitations in mind, it is beyond the scope of this paper to investigate the various solutions proposed.

It is interesting to note that in Table $1 \mathrm{c}$ the overall figure of $\mathbf{1 4}$ for deaths from respiratory disease is almost identical with the numbers expected from the England and Wales rate, namely 13.85 . These figures include bronchitis (Table 4), from which 6 deaths were observed and 8.13 expected. Calculation of the expected deaths from bronchitis using the S.E. Wales mortality rates shows an even higher expected number of $10 \cdot 25$ which is considerably larger than the observed number of 6 .

In the malignant neoplasms group it is surprising that despite the far higher than normal exposures of some of the population to $3: 4$ benzpyrene, the observed deaths from lung cancer were lower than expected, 8 compared with $\mathbf{9 \cdot 7 6}$ (Table 2). It has not been possible to detect any statistically significant increase in mortality rates from the causes which would have been expected from occupational exposure to this acknowledged carcinogen. The environmental measurements indicate that the levels of $3: 4$ benzpyrene around the two Works were 50-100 times the winter levels and 250-500 times the summer levels experienced in cities. It would therefore appear that the relationship between cancer (particularly lung cancer) and 3:4 benzpyrene, is far from linear, thus confirming earlier workers' findings in gas works, (Kreyberg, 1959; Lawther et al., 1965). Sawicki (1967) has suggested that attempts to correlate carcinogenicity of mixtures in the chemical environinent with the concentration of $3: 4$ benzpyrene present are naive in most cases. The remaining subgroups showed fair agreement between observed and expected deaths with the exception of two, neoplasms of bladder and kidney, and those in the rectum and colon. These showed slightly higher observed numbers than expected, 5 instead of 2.6 for rectum and colon and 3 instead of 1.19 for bladder and kidney.

Among cardiovascular diseases (Table 3 ) the subgroup showing the most interesting trend is B26a. Up to age 54 the observed and expected deaths were similar (4 compared with 3.78); however, the next two age groups show a remarkable difference between observed and expected deaths, 5 observed compared with $19 \cdot 16$ expected, which is not compensated for in any of the other subgroups and for which there is no obvious explanation. This difference is further emphasised if the observed total number of deaths (10) under B26a is compared with the expected number $(27 \cdot 44)$ calculated from the S.E. Wales mortality rates. This difference is significant at the $P=$ 0.001 level with 1 degree of freedom.
It is well known that occupations involving habitual physical activity show lower mortality rates from cardiovascular causes than the more sedentary occupations. Statistical evidence supports the view that incidence, prevalence and mortality rates from coronary heart disease vary inversely with the average levels of exercise involved in different occupations (Morris et al., 1953; Yasin et al., 1967). However this would not account for the differences shown in subgroup B26a.

Seven of those ten subgroups (Table 5) which include 'other causes' show fair agreement; the three which differ are deaths from renal (6 observed, 1.40 expected) trauma (2 observed, 3.45 expected) and other causes (none was observed and 2.76 expected). Bearing in mind that the industry being studied is considered to be heavy, and that environmental conditions of heat and pollution are often severe, the better than expected figures for trauma are surprising and reflect well on the Medical and Safety Departments of the Works concerned.

I wish to thank Professor C. R. Lowe, Department of Social and Occupational Medicine, Welsh National School of Medicine, Cardiff, from which the work was carried out, for permission to use these data and Professor H. Campbell, Department of Medical Statistics at the School, for his help in planning the investigation and analysing the results. I would also like to express my gratitude to the management and work force at the two works for their whole-hearted support, to the Registrar General's Office for the help given and to the Nuffield Foundation whose grant helped to finance the project. Finally I would like to thank the British Steel Corporation for permission to publish this paper.

\section{References}

Doll, R. (1952). Causes of death among gas workers with special reference to cancer of the lung. British Journal of Industrial Medicine, 9, 180-185.

Doll, R., Fisher, R. E. W., Gammon, E. J., Gunn, W., Hughes, C. O., Tyrer, F. H., and Wilson, W. (1965). Mortality of gas workers with special reference to cancers of the lung and bladder, chronic bronchitis and pneumoconiosis. British Journal of Industrial Medicine, 22, 1-12.

Kennaway, E. L., and Kennaway, N. M. (1947). Further study of incidence of cancer of lung and larynx. British Journal of Cancer, 1, 260-298.

Kreyberg, L. (1959). 3:4 benzpyrene in industrial air pollution: some reflections. British Journal of Cancer, 13, 618622.

Lawther, P. J., Commins, B. T., and Waller, R. E. (1965). A study of the concentration of polycyclic aromatic hydrocarbons in gas works retort houses. British Journal of Industrial Medicine, 22, 13-20.

Lloyd, J. W. (1971). Long term mortality study of steelworkers. V. Respiratory cancer in coke plant workers. Journal of Occupational Medicine, 13, 53-68. 
Lloyd, J. W., and Ciocco, A. (1969). A long term mortality study of steelworkers. I. Methodology. Journal of Occupational Medicine, 11, 299-310.

Lloyd, J. W., Lundin, Jr. F. E., Redmond, C. K., and Geiser, P. B. (1970). Long term mortality study of steelworkers. IV. Mortality by work area. Journal of Occupational Medicine, 12, 151-157.

Lowe, C. R., Campbell, H., and Khosla, T. (1970). Bronchitis in two integrated steel works. III. Respiratory symptoms and ventilatory capacity related to atmospheric pollution. British Journal of Industrial Medicine, 27, 121-129.

Lowe, C. R., Pelmear, P. L., Campbell, H., Hitchens, R. A. N., Khosla, T., and King, T. C. (1968). Bronchitis in two integrated steelworks. I. Ventilatory capacity, age and physique of non-bronchitic men. British Journal of Preventive and Social Medicine, 22, 1-11.

Mazumdar, S., Redmond, C., Sollecito, W., and Sussman, N. (1975). An epidemiological study of exposure to coal tar pitch volatiles among coke oven workers. Journal of the Air Pollution Control Association, 25, 382-389.

McMichael, A. J. (1976). Standardised Mortality Ratios and the 'Healthy worker effect': scratching beneath the surface. Journal of Occupational Medicine, 18, 165-168.

Morris, J. N., Heady, J. A., Raffle, P. A. B., Roberts, C. G. and Parks, J. W. (1953). Coronary heart disease and physical activity of works. Lancet, 2, 1053-1057.

Redmond, C. K., Ciocco, A., Lloyd, J. W., and Rush H. W. (1972). Long term mortality study of steelworkers. VI.
Mortality from malignant neoplasms among coke oven workers. Journal of Occupational Medicine, 14, 621-629.

Redmond, C. K., Smith, E. M., Lloyd, J. W., and Rush, H. W. (1969). Long term mortality study of steelworkers. III. Follow-up. Journal of Occupational Medicine, 11, 513521.

Registrar General (1960-63). Statistical Reviews of England and Wales for the years 1958-1961; Part 1, Tables, Medical. HMSO: London.

Reid, D. D., and Buck, C. (1956). Cancer in coking plant workers. British Journal of Industrial Medicine, 13, 265-268.

Robinson, H. (1969). Long term mortality study of steelworkers. II. Mortality by level of income in whites and nonwhites. Journal of Occupational Medicine, 11, 411-416.

Sawicki, E. (1967). Airborne carcinogens and allied components. Archives of Environmental Health, 14, 46-53.

Special Communications (1975). Journal of Occupational Medicine, 17, 126-131.

Warner, C. G., Davies, G. M., Jones, J. G., and Lowe, C. R. (1969). Bronchitis in two integrated steel works. II. Sulphur dioxide and particulate atmospheric pollution in and around the two works. Anrals of Occupational Hygiene, $12,151-170$.

Yasin, S., Alderson, M. R., Marr, J. N., Pattison, D. C., and Morris, J. N. (1967). Assessment of habitual physical activity apart from occupation. British Journal of Preventive and Social Medicine, 21, 163-169. 
A small increase in the yield of SCEs was found at both of the concentrations which permitted metaphase production $(\mathrm{P}<0.05$ for the concentration of $0.270 \mu \mathrm{g} / \mathrm{ml}$ and $\mathrm{P}<0.001$ at $2.70 \mu \mathrm{g} / \mathrm{ml})$. No stable aberrations (fragments, rings or dicentrics) were observed in any of the lymphocyte cultures examined.

The values given in Tables 1 and 2 may be compared with data from Perry and Evans (1975) for SCE induction by various known mutagens, many of which produce large numbers of exchanges. Quinacrine mustard, for example, gave an SCE value of $121 \cdot 1$ per cell at a concentration of $10^{-6} \mathrm{M}$. The present data therefore suggest that the limited ability to induce gross structural abnormalities in chromosomes is probably not a major hazard of DTPA or of its lipophilic derivative. However, the absence of mitotic figures at higher concentrations of both materials suggests some further toxic effect, possibly associated with the removal of metal ions from the culture medium or even from the cell membranes.

DTPA and its lipophilic derivative were kindly provided by Dr Robert Bulman.

\section{References}

Bridges, B. A. (1976). Short term screening tests for carcinogens. Nature, 261, 195-200.

Brugsch, H. G., Colombo, N. J., and Pagnotto, L. D. (1965). Chelation by calcium trisodium pentetate in workers exposed to lead. New England Journal of Medicine, 272, 993-996.
Bulman, R. A., Griffin, R. J., and Russell, A. T. (1976). The Development of New Chelating Agents for Removing Plutonium from Intracellular Sites. National Radiological Protection Board Annual Research and Development Report No. 1, pp. 87-89. NRPB: Harwell.

Cohn, N.S. (1961). The effect of chelation and the production of chromatid aberrations in Vicia faba. Experimental Cell Research, 24, 596-599.

Fahey, J. L., Rath, C. E., Princiotto, J. V., Brick, I. B., and Rubin, M. (1961). Evaluation of trisodium calcium diethylenetriaminepentaacetate in iron storage disease. Journal of Laboratory and Clinical Medicine, 57, 436-449.

Michaelis, A., Nicoloff, H., and Rieger, R. (1962). Influence of EDTA on the induction of chromatid aberrations by triethylene melamine and ethyl alcohol. Biochemical and Biophysical Research Communications, 9, 280-284.

Morgan, R. M., and Smith, H. (1974). Histological changes in kidney, liver and duodenum of the mouse following the acute and subacute administration of diethylenetriaminepentaacetic acid. Toxicology, 2, 153-163.

Perry, P., and Evans, H. J. (1975). Cytological detection of mutagen-carcinogen exposure by sister chromatid exchange. Nature, 258, 121-125.

Perry, P., and Wolff, S. (1974). New Giemsa method for the differential staining of sister chromatids, Nature, 251, 156-158.

Purrott, R. J., and Lloyd, D. C. (1972). The Study of Chromosome Aberration Yield in Human Lymphocytes as an Indicator of Radiation Dose. I. Techniques. National Radiological Protection Board Report No. 2. NRPB: Harwell.

Schofield, G. B., and Dolphin, G. W. (1974). UK experience in the medical aspects of radiological protection of workers handling plutonium. Annals of Occupational Hygiene. 17, 73-83.

Stack, T. L., and Fox, C. F. (1972). In Membrane Molecular Biology, pp. 27-75. Edited by C. F. Fox and A. D. Keith. Sinauer Associates Inc: Stamford.

Stetka, D. G., and Wolff, S. (1976). Sister chromatid exchange as an assay for genetic damage induced by mutagencarcinogens. II. In vitro test for compounds requiring metabolic activation. Mutation Research, 41, 343-350.

\section{Erratum}

\section{A mortality study of coke oven workers in two South Wales integrated steelworks}

\section{G. M. DAVIES}

It is regretted that there was an error in this paper (British Journal of Industrial Medicine (1977) 34, 291-297) which affected the estimate of the total man-years of survival. The study was based on 610 men, all of whom were employed in 1954 and $100 \%$ of whom were traced to death or survival in June, 1965. The age-specific man-years were calculated from a double decrement table in single years of age for each calendar year and deaths were assumed to occur at the mid-year. This allowed 5-year age groups to be obtained and the 'expected' deaths were calculated from the national age-specific rates. Unfortunately in this calculation the first and last years were considered as full years whereas, in fact, the deaths were registered for only half of these two years. This resulted in an incorrect estimate of 6837 man-years which was $9 \%$ above the true total of $6261 \cdot 5$ man-years. The numbers of 'expected' deaths are reduced almost proportionally causing a related increase in the SMRs. The recalculated SMRs are:- Works A, 107\%; Works B, $78 \%$; Works A + B, $92 \%$; as compared with the published SMRs for Works A, 98\%; Works B, $73 \%$; Works A + B, $85 \%$.

The general findings of this paper, however, are not affected; in particular, in the population studied, the observed and expected deaths were not very different for respiratory disease (14 observed, $12 \cdot 6$ expected), cancer of the lung ( 8 observed, 8.94 expected) and cancer of the bladder and kidney (3 observed, 1.09 expected). The marked deficiency of cardiovascular disease is still apparent (29 observed, 41.36 expected).

A corrected paper can be obtained from the author, British Steel Corporation, Welsh Laboratory and Strip Mills Products, Port Talbot, W. Glam. 